\title{
High-Quality Development of the Modern Service Industry in Fuzhou, China
}

\author{
CHEN GUOTIE \\ School of Management, Fujian University of Technology \\ CHINA
}

\begin{abstract}
The development level of the modern service industry is a crucial measure of a city's comprehensive strength, regional competitiveness, development potential, and degree of modernization. Since the 13th FiveYear Plan, Fuzhou's three major industries (the primary industry is agriculture, the secondary is industry and the tertiary is the service industry) have undergone substantial structural changes: the tertiary industry now contributes to half of the total gross domestic product, and the era of the service economy has arrived. This paper provides a comprehensive review of Fuzhou's service industry development, and it includes a comparative analysis of service industry development between coastal and inner Fuzhou. Furthermore, this paper identifies gaps and insufficiencies in Fuzhou's service industry and provides suggestions for promoting the high-quality development of the modern service industry in Fuzhou from the perspective of service sectors such as finance, retail, and logistics.
\end{abstract}

Key-Words: - Fuzhou, Modern Service Industry, High-Quality Development

Received: April 5, 2021. Revised: October 20, 2021. Accepted: November 3, 2021. Published: November 22, 2021.

\section{Introduction}

Modern service industry plays an irreplaceable role in improving the comprehensive function and strength of the city. The modern service level of a city reflects the development level of the modern service industry of the city or region. To promote the economic development of the whole city or region through the development of modern service industry is an important way to achieve high-quality economic development in China. In the fierce international competition environment, if China wants to maintain sound and rapid economic development, it still needs to vigorously develop modern service industry and drive the economy of the city and even the whole country with the development of modern service industry[1].

Throughout the development of the service industry, in the pursuit of quantity, the service industry has drawn an upward development curve, showing a strong trend of development. However, entering a new era characterized by rapid growth to high-quality development, is China's modern service industry still in the growth stage of factor expulsion? In the qualitative test, many scholars have started from exploring the applicability and correctness of Baumol's cost disease to measure the productivity of China's service industry. Some studies believe that the growth of labor productivity in service industry lags behind, while some studies have obtained reverse results, believing that the total factor productivity in service industry increases significantly, and the TFP of service industry is higher than that of industry under environmental constraints. The equal dimension of innovation level and openness industrial integration has also become a research point for the development quality of service industry. However, there are few existing literatures that comprehensively measure the development level of modern service industry, and the index system is thin and fails to reflect the internal requirements of high-quality development.

The research on the high-quality development of modern service industry is still in its infancy. Many scholars start from discussing the urgency of the high-quality development of service industry and explain that the high-quality development of service industry provides important support for the steady and long-term development of China's economy. $\mathrm{Li}$ Ping et al. (2017) demonstrate that producer services can serve as a new driving force for China's economic growth in the future, and demonstrate that high-quality development of services is particularly important for China's stable economic growth[2]. Yao Zhanqi (2019) explained the positive impact of service industry on the upgrading of China's industrial structure from the perspective of openingup[3]. Wang Jiayuan et al. (2018) discussed that the service industry is a key force to push the economy towards high-quality development by analyzing the current economic situation[4]. Therefore, to 
stabilize the economic foundation and strengthen the economic power, it is necessary to promote the development of service industry to a new level. However, there is still a big gap between the development level of modern service industry in China and the requirements of high quality. Scholars have pointed out strategies for the high-quality development of service industry. Aiming at the painful points and difficulties in the development of the industry, Lai Youwei (2018) believes that efforts should be made in the following five aspects: openness of the management system of the service industry, industry standards and the reform of highend talent supply in standardized monopolistic industries[5]. Liu Yi and Xia Jiechang (2018) point out that the three major tasks in the high-quality development stage of service industry are industry integration and service innovation and transformation and upgrading of traditional service industry, which are also where its development potential lies[6]. Xia Jiechang and Xiao Yu (2019) emphasized the importance of improving the level of opening up and international competitiveness when analyzing the transformation, upgrading and optimization of producer services[7]. Existing literature mainly focuses on explanatory research and policy interpretation, but quantitative research on the high-quality development of modern service industry is obviously insufficient. Based on this, the research on the high-quality development of modern service industry will be carried out in the following aspects.

Firstly, the theoretical basis of modern service industry is summarized, and then the development of service industry in Fuzhou is summarized. Thus the basic opportunities and challenges of highquality development of Fuzhou service industry during the 14th five-year plan are analyzed. In view of the problems existing in the modern service industry of Fuzhou, the paper puts forward some suggestions on the development of high quality. The last part is the conclusion and discussion, and the prospect of future research is put forward.

\section{Theoretical Basis of the Modern Service Industry}

Victor R. Fuchs, an American economist, was the first economist to systematically study the service industry[4]. His 1968 publication The Service Economy was the world's first landmark composition on the service economy. Fuchs proposed using the proportion of the service industry's working population as the standard for a country or region entering into the service economy. That is, more than half of the working population must not be involved in the production of food, clothing, housing, automobiles, or other materials [5].

With the development of service economy theory, which encompasses the concepts contribution to economic growth, in the service economy era, the engine of economic growth has changed from investment to consumption. In terms of industrial structure, the modern service industry includes five main economic service activities: output, employment, consumption, trade, and investment. In terms of product servitization, Philip Kotler, an American marketing management scientist, proposed the three-layer theory of product structure, which consists of the core, tangible, and additional product layers. The core product layer is the use value or utility of the product; the tangible product layer includes the brand name, packaging, name, and style of the product; and the additional product layer is the additional service or extended value of the product. The three-layer structure of the product is an interrelated organic fusion body reflecting the integrity and indivisibility of the physical product and service. Additionally, the three-layer structure represents the development of the manufacturing industry to a certain stage; moreover, the service industry must adapt to the extension of the product's connotation and development.

China has recently entered a new stage of development, with "high-quality development" as the main theme. Therefore, to comprehensively promote the transformation and improvement of the manufacturing industry, the modern service industry must be substantially developed, the producer service industry must be upgraded to a professional, high-end value chain, and the lifestyle service industry must be enhanced and diversified.

\section{The Fuzhou Service Industry's Entrance into the Modern Era}

\subsection{Dominance of the Service Industry}

Since the beginning of the 21 st century, the development of the service industry in Fuzhou has accelerated due to the introduction of a series of related policies and measures. The added value of Fuzhou's three major industries more than tripled from 152.07 billion yuan in 2010 to 503.484 billion yuan in 2019. Table 1 illustrates that the proportion of the service industry associated with the regional 
gross domestic product (GDP) of Fuzhou also increased rapidly. In 2016, the proportion of value added by the service industry to the tertiary industry exceeded $50 \%$ in the first year of the 13th Five-Year Plan and accounted for $50.26 \%$ of regional GDP [5]. The service industry provides a strong driving force for Fuzhou's future high-quality development and economic growth.

Table 1. Fuzhou's Three Industrial Added Value scale of and its Proportion in GDP

\begin{tabular}{|c|c|c|c|c|c|}
\hline Year & $\begin{array}{c}\text { Added } \\
\text { Value of } \\
\text { primary } \\
\text { industry/bi } \\
\text { llion yuan }\end{array}$ & $\begin{array}{c}\text { Added Value } \\
\text { of secondary } \\
\text { industry/billi } \\
\text { on yuan }\end{array}$ & $\begin{array}{l}\text { Added Value } \\
\text { of tertiary } \\
\text { industry/billi } \\
\text { on yuan }\end{array}$ & $\begin{array}{c}\text { GDP/ } \\
\text { billio } \\
\text { n } \\
\text { yuan }\end{array}$ & $\begin{array}{l}\text { The } \\
\text { proportion of } \\
\text { the added } \\
\text { value of the } \\
\text { three } \\
\text { industries }\end{array}$ \\
\hline 2010 & 26.16 & 146.04 & 152.07 & $\begin{array}{c}324.2 \\
7\end{array}$ & $\begin{array}{l}9.05: 45.80: 46 \\
02\end{array}$ \\
\hline 2015 & 38.18 & 255.67 & 283.89 & $\begin{array}{c}577.7 \\
4\end{array}$ & $\begin{array}{l}7.74: 43.60: 48 \\
66\end{array}$ \\
\hline 2016 & 49.23 & 259.04 & 311.50 & $\begin{array}{c}619.7 \\
6\end{array}$ & $\begin{array}{l}7.94: 41.80: 50 \text {. } \\
26\end{array}$ \\
\hline 2017 & 46.12 & 291.34 & 371.09 & $\begin{array}{c}708.5 \\
5\end{array}$ & $\begin{array}{l}6.15: 41.12: 52 \\
37\end{array}$ \\
\hline 2018 & 49.47 & 320.49 & 415.73 & $\begin{array}{c}785.6 \\
8\end{array}$ & $\begin{array}{l}6.30: 40.79: 52 \\
91\end{array}$ \\
\hline 2019 & 52.65 & 383.10 & 503.48 & $\begin{array}{c}939.2 \\
3\end{array}$ & $\begin{array}{l}5.60: 40.80: 53 \\
60\end{array}$ \\
\hline
\end{tabular}

Data resources: 2020 Fuzhou City Statistical Yearbook

The service industry's contribution to regional GDP growth has increased substantially. As displayed in Table 2, the service industry's proportion of GDP growth steadily increased from $39.5 \%$ in 2010 at the end of the 11th Five-Year Plan period to $42 \%$ in 2014. By the end of the 12th Five-Year Plan (20112015), the tertiary industry's contribution of GDP growth had surpassed that of the secondary industry, that is, the industry ultimately reaching 59\%[6]. During the 13th Five-Year Plan period, the equipment manufacturing industry developed substantially, and the tertiary industry continuously adjusted. By 2019, GDP growth contribution had stabilized at $55 \%$, and the tertiary industry had become a critical engine and main pillar of Fuzhou's economic growth[7].

Table 2. Contribution of Fuzhou Tertiary Industry to Economic Growth

\begin{tabular}{ccccc}
\hline Year & $\begin{array}{l}\text { Contribution of the } \\
\text { primary } \\
\text { industry }(\%)\end{array}$ & $\begin{array}{l}\text { Contribution of the } \\
\text { secondary } \\
\text { industry (\%) }\end{array}$ & $\begin{array}{l}\text { Contribution of the } \\
\text { tertiary } \\
\text { industry }(\%)\end{array}$ \\
\hline 2010 & 2.2 & 58.4 & 39.5 \\
2014 & 3.2 & 54.8 & 42.0 \\
2015 & 2.8 & 37.9 & 59.3 \\
2016 & 3.7 & 34.7 & 61.6 \\
2017 & 2.8 & 43.4 & 53.8 \\
2018 & 3.0 & 42.1 & 54.9 \\
2019 & 2.8 & Fuzhou & City & Statistical \\
Data resources: & 2020 & &
\end{tabular}

\subsection{Increased Employment in the Service Industry}

With Fuzhou's economic development and increases in per capita national income, the service industry continues to expand; consequently, substantial portion of the working population has gradually transferred to the service industry. As shown in Table 3, service industry employment increased from 467,367 in 2010 to 698,502 by the end of 2019, with a net increase of more than 230,000 (or a growth rate of $49.46 \%$ )[8]. This indicates that the service industry in Fuzhou has achieved scale expansion and enhanced employment transfer capacity. Additionally, the employment rate of the service industry in the same period was stable at approximately $46 \%$, which reflects the stability and structural optimization of the service industry. According to the data in Table 3, the movement of the working population toward the service industry in Fuzhou also conforms to the Petty-Clark Law. That is, the relative proportions of national income and workforce have been gradually decreasing in the primary industry, that is, agriculture and gradually increasing in the tertiary industry. Accordingly, the working population has been shifting from the primary industry to the secondary industry[9]. Furthermore, along with the trend toward economic and social development as well as the development of the service industry, economic development is reaching new heights[10].

Along with changes in the working population of the tertiary industry in Fuzhou in 2018 and 2019, changes in the working population of the primary and secondary industries also reflect a common characteristic of developing countries[11]. The workforce does not first change from agriculture to manufacturing and then from manufacturing to the service industry; rather, the workforce changes directly from agriculture to the service industry, reflecting the rationality and scientificity of structural industrial changes in Fuzhou.

Table 3. The Number and Proportion of Employment in Three Industries in Fuzhou

\begin{tabular}{|c|c|c|c|c|c|}
\hline Year & $\begin{array}{l}\text { Employe } \\
\text { es in the } \\
\text { primary } \\
\text { industry }\end{array}$ & $\begin{array}{l}\text { Employee } \\
\mathrm{s} \text { in the } \\
\text { secondary } \\
\text { industry }\end{array}$ & $\begin{array}{l}\text { Employee } \\
\mathrm{s} \text { in the } \\
\text { tertiary } \\
\text { industry }\end{array}$ & $\begin{array}{l}\text { Total } \\
\text { employee } \\
\mathrm{s} \text { of the } \\
\text { whole } \\
\text { society } \\
/ 10 \\
\text { thousand }\end{array}$ & $\begin{array}{l}\text { The proportion } \\
\text { of employment } \\
\text { in the three } \\
\text { industries }\end{array}$ \\
\hline 2010 & 6981 & 526766 & 467367 & 1001114 & $\begin{array}{l}0.70: 52.62: 46.6 \\
8\end{array}$ \\
\hline 2015 & 1888 & 809000 & 601858 & 1412746 & $\begin{array}{l}0.13: 57.26: 42.6 \\
0\end{array}$ \\
\hline 2016 & 2081 & 793172 & 616294 & 1411547 & $\begin{array}{l}0.15: 56.19: 43.6 \\
6\end{array}$ \\
\hline 2017 & 2593 & 764977 & 638772 & 1406342 & $\begin{array}{l}0.18: 54.39: 45.4 \\
3\end{array}$ \\
\hline 2018 & 1702 & 861882 & 676141 & 1539725 & 0.11:55.98:43.91 \\
\hline
\end{tabular}




\begin{tabular}{lllllll}
\hline 2019 & 716 & 804894 & 698502 & 1504112 & \multicolumn{2}{c}{$0.05: 53.51: 46.4$} \\
& & & & \\
\hline $\begin{array}{l}\text { Data } \\
\text { Yearbook }\end{array}$
\end{tabular}

In 2019, Fuzhou's service industry workforce accounted for $46.44 \%$ of the total workforce, which is close to that of Professor Fuchs' standard service economy workforce ratio[12]. This indicates that Fuzhou will enter the service economy era during the 14th Five-Year period.

\subsection{Internal Composition of Fuzhou's Service Industry}

According to national statistics, the added value of the service industry consists of seven subindustries, including transportation, warehousing, postal services, wholesale and retail, catering, finance and real estate. Other services include agriculture, forestry, animal husbandry and fishery, geological exploration services, water conservation, health, sports, social welfare, education, literature and art, radio, television, film, scientific research, comprehensive technical services, state organizations, political parties, and public organizations [9]. As displayed in Table 4, the main service sectors in Fuzhou are wholesale and retail, catering, and finance. Since 2010, the relative share of the service sector in the economy has remained approximately $20 \%$. Although this proportion has decreased in recent years, the service sector still accounts for one-fifth of the total economy.

The financial industry in Fuzhou has developed rapidly in the past decade, the relative share surging from $12.62 \%$ in 2010 to $19.97 \%$ in 2019 , stabilizing as one-fifth of the service sector. Moreover, provincial capitals are playing an increasingly important role as regional financial centers. Since 2010, the relative share of transportation, storage, and postal services in the added value of the service industry has decreased (from $10.89 \%$ in 2010 to $6.25 \%$ in 2019)[10]. This demonstrates that although the momentum of modern logistics development is strong, Fuzhou's logistics industry development is slow; consequently, prospects are not encouraging.

\section{Conclusion}

Please, follow our instructions faithfully, otherwise you have to resubmit your full paper. This will enable us to maintain uniformity in the conference proceedings as well as in the post-conference luxurious books by Press. Thank you for your cooperation and contribution. We are looking forward to seeing you at the Conference.

Table 4. Composition and Proportion of Added Value of Service Industry in Fuzhou

\begin{tabular}{|c|c|c|c|c|c|c|}
\hline $\begin{array}{l}\mathrm{Ye} \\
\text { ar }\end{array}$ & $\begin{array}{c}\text { Added } \\
\text { value of } \\
\text { the } \\
\text { tertiary } \\
\text { industry } \\
(\%)\end{array}$ & $\begin{array}{c}\text { Transport } \\
\text { ation } \\
\text { warehous } \\
\text { e postal } \\
\text { storage } \\
\text { industry } \\
(\%)\end{array}$ & $\begin{array}{l}\text { Wholesal } \\
\text { e and } \\
\text { retail } \\
\text { catering } \\
\text { industry } \\
(\%)\end{array}$ & $\begin{array}{c}\text { Finance } \\
(\%)\end{array}$ & $\begin{array}{c}\text { Real } \\
\text { estate } \\
\text { industry } \\
(\%)\end{array}$ & $\begin{array}{c}\text { Others } \\
\%)\end{array}$ \\
\hline $\begin{array}{l}20 \\
10\end{array}$ & 100 & 10.89 & 26.46 & 12.62 & 9.21 & 40.82 \\
\hline $\begin{array}{l}20 \\
15\end{array}$ & 100 & 8.02 & 22.96 & 20.30 & 9.74 & 38.97 \\
\hline $\begin{array}{l}20 \\
16\end{array}$ & 100 & 7.03 & 22.43 & 20.07 & 10.92 & 39.56 \\
\hline $\begin{array}{l}20 \\
17\end{array}$ & 100 & 7.17 & 21.52 & 20.22 & 11.51 & 39.59 \\
\hline $\begin{array}{l}20 \\
18\end{array}$ & 100 & 6.43 & 20.93 & 19.54 & 12.34 & 40.76 \\
\hline $\begin{array}{l}20 \\
19 \\
\end{array}$ & 100 & 6.25 & 20.55 & 19.97 & 12.62 & 40.61 \\
\hline
\end{tabular}

Data resources: 2020 Fuzhou City Statistical Yearbook

\section{High-Quality Development of Fuzhou's Service Industry: Foundation, Opportunities, and Challenges}

\subsection{Development Foundation}

In recent years, Fuzhou government has taken full advantage of its unique environmental location by enacting beneficial policies in the five zones, including the core area of the 21st Century Maritime Silk Road, the Free Trade Zone, and the National New Area. Development of the service industry has been considered extremely crucial, and a series of proposals have been introduced, including the Work Plan for the Leap-forward Development and Upgrading of the Service Industry in Fuzhou (20182020), the Work Plan on Promoting the Construction of Modern Service Industry Cluster, and the Work Plan on Promoting the Creation (Improvement) of the Upper Limit and the Upper Limit of Commercial and Trade Service Enterprises[11]. These proposals will comprehensively promote the "leap-forward" development of the service industry. The first proposal recommends developing Fuzhou as the center of the 21 st century Maritime Silk Road service industry. In 2020, the added value of the entirety of Fuzhou's service industry is expected to surpass 500 billion yuan, which would account for more than $54 \%$ of the total economy. The achievement by the end of 2019, laying a solid foundation for the development of Fuzhou's service industry and the creation of a modern service 
industry center in accordance with the 14th FiveYear Plan[12].

Driven by the revolution in information technology and industrial reforms, the service industry in Fuzhou achieved leap-forward development during the 13th Five-Year Plan period, effectively facilitating the construction of three urban centers in Fuzhou. Traditional industries expedited digital transformation and improvement, the new economy developed rapidly, and the business services industry developed substantially[14]. In particular, the business and nightlife economies, with urban commercial centers at their cores, are becoming increasingly prosperous, intelligent, and crucial. The first constituent element of this observed growth is the steady development of trade and service enterprises. By the end of 2019, the number of regulated service enterprises in Fuzhou had reached 1,956 , and the number of regulated trade and service enterprises had reached 3,363. Second, supply-side structural reform was promoted to meet new demand, and with the assistance of new technology, new retail enterprises were substantially developed[15]. In 2018, Fuzhou government was the first to propose the development of the nationally famous "new retail capital" by integrating new modes of online and offline development; specifically, Fuzhou established modern smart convenience stores, smart business circles, smart logistics operations, and other new retail industries. A series of new retail brands such as Pupu online market, and Yonghui Daojia have been continually expanding. Concurrent with this development, Fuzhou continued to expand and strengthen the traditional business and retail industry by integrating the city's business district with commercial centers and large department stores. The business district will be upgraded to a super business circle with multiple elements such as an urban commercial center, large department stores, and characteristic city blocks. The new business district will promote the formation of the "night block" and the "night river" in the Fuzhou "night economic circle," facilitating the development of the commercial branding "Night Fuzhou, Happy City." Furthermore, producer services have begun to take shape to meet new demand, actively promoting the serviceoriented transformation of the manufacturing industry. By the end of 2019, Fuzhou had completed five key producer service projects at the provincial level, 29 provincial service-oriented manufacturing demonstration enterprises, 25 demonstration enterprises, and 15 public service platforms. Moreover, this strategy has stimulated local industries; a modern service industry cluster has begun to form. Currently, a modern logistics park, creative industry park, e-commerce industry park, information service industry park, modern professional trading market, and comprehensive modern service industry cluster are under construction.

\subsection{Development Opportunities}

The Fifth Plenary Session of the 19th CPC Central Committee proposed several suggestions, one of which was the development of industries specifically for expediting the modernization of the service industry to create a new system of operation, ease market access, and promote the development of efficient, high-quality services. Additionally, to update producer services to a professional grade and extend the value chain to high-end consumer services, manufacturing is converted from traditional production to producer services to develop the tourism industry. The CPC and the government have made systematic, strategic plans for the future development of the service industry; these plans provide a clear direction for growth and supporting conditions for the high-quality development of the service industry in Fuzhou. In recent years, the CPC Central Committee has considered the development of Fujian to be extremely crucial, endowing Fujian with the sacred mission and historic responsibility of comprehensively promoting high-quality development to complete the construction of a new Fujian and build the first home for Taiwanese compatriots and enterprises. Fuzhou is the capital of Fujian, the political center of Fujian's regional economic center, and the central city of Haixi. Fuzhou has the tremendous responsibility and obligation to assist Fujian in achieving major strategic goals. Concurrently, Fuzhou is also building a modern financial center in Haixi as a national logistics hub and a modern service industry center on the Maritime Silk Road, which also provides opportunities and regional advantages for the high-quality development of Fuzhou's service industry[16].

\subsection{Issues and Challenges}

During the 13th Five-Year Period, Fuzhou's service industry made great progress and remarkable achievements; however, difficulties and shortcomings also ensued. Compared with the capital cities of the surrounding developed provinces, an economic gap existed between Fuzhou and the other cities, which was reflected in the small scale and limited competitiveness of Fuzhou's service industry[17]. As displayed in Table 5, 
compared with some provincial capitals along the coast, the overall scale of the service industry in Fuzhou was modest, and the industry's capability was limited; the economic gap was obvious. In 2019, the total value of Fuzhou's tertiary industry was 503.48 billion yuan, which was only $29.75 \%$ of Guangzhou's, $49.5 \%$ of Hangzhou's, and $86.28 \%$ of Jinan's tertiary industry value[18]. The contribution of Fuzhou's service industry to the national economy remains low at only 55\%, whereas Guangzhou's and Hangzhou's service industries had contributed more than 70\%; Jinan's contribution was approximately $60 \%$. In terms of the proportion of the regional national economy, the tertiary industry in Guangzhou reached $71.62 \%$, the proportion was more than $60 \%$ in Hangzhou, Nanjing, and Jinan[19]; however, Fuzhou's only reached slightly more than $50 \%$. Considerable gaps in development are evident, and the overall level of development remains relatively low. Continuously optimizing the structure of tertiary industries remains arduous. In terms of the added value growth rate of the tertiary industry, the growth momentum of each city is similar. However, Guangzhou and Hangzhou cannot easily achieve substantial growth, even with a considerable consumer base. Although Fuzhou has a growth rate of $8.3 \%$, the economic gap will gradually continue to widen due to the limited consumer base.

Table 5. Comparison of Service Industry Development in Five Coastal Capital Cities in 2019

\begin{tabular}{cccccc}
\hline $\begin{array}{c}\text { Tertiary } \\
\text { industry/city }\end{array}$ & Fuzhou & Guangzhou & Hangzhou & Nanjing & Jinan \\
\hline $\begin{array}{c}\text { Total } \\
\text { value (billion } \\
\text { yuan) }\end{array}$ & 503.48 & 1692.32 & 1017.2 & 869.95 & 583.51 \\
$\begin{array}{c}\text { Proportion in } \\
\text { GDP } \\
\text { contribution } \\
\text { degree to } \\
\text { national } \\
\text { economy }\end{array}$ & $53.60 \%$ & $71.62 \%$ & $66.2 \%$ & $62 \%$ & $61.8 \%$ \\
$\begin{array}{c}\text { The proportion } \\
\text { of service } \\
\text { industry in } \\
\begin{array}{c}\text { Fuzhou and } \\
\text { other cities }\end{array}\end{array}$ & $55.00 \%$ & $73.7 \%$ & $72.9 \%$ & $67.4 \%$ & $59.3 \%$ \\
$\begin{array}{c}\text { Increase rate of } \\
\text { tertiary industry }\end{array}$ & $8.3 \%$ & $29.75 \%$ & $49.50 \%$ & $57.88 \%$ & $86.28 \%$ \\
\hline
\end{tabular}

Data resource: 2020 Statistical Yearbook of Five cities along the coast, 2019 statistical bulletin of the national economic and social development

To facilitate research, the financial industry, one of the major sectors of the modern service industry, was analyzed; the development situation in the financial industry was compared among five provincial capitals along the eastern coast in 2019.

Table 6. Comparison of Financial Industry Development of Five Coastal Capital Cities in 2019

\begin{tabular}{|c|c|c|c|c|c|}
\hline Tertiary industry/city & Fuzhou & Guangzhou & Hangzhou & Nanjing & Jinan \\
\hline $\begin{array}{l}\text { Added value of finance } \\
\text { industry (billion } \\
\text { yuan) }\end{array}$ & 100.54 & 204.19 & 178.9 & 84.93 & 89.25 \\
\hline $\begin{array}{l}\text { The proportion of the } \\
\text { service sector in the } \\
\text { same period }(\%)\end{array}$ & $19.97 \%$ & $12 \%$ & $17.58 \%$ & $9.76 \%$ & $15.29 \%$ \\
\hline $\begin{array}{l}\text { Percentage in GDP in } \\
\text { the same period }(\%)\end{array}$ & $10.7 \%$ & $8.6 \%$ & $11.63 \%$ & $6.05 \%$ & $9.44 \%$ \\
\hline
\end{tabular}

Data resource: 2020 Statistical Yearbook of Five cities along the coast, 2019 statistical bulletin of the national economic and social development

As displayed in Table 6, as a financial industry, the added value of Fuzhou is ranked in the top five provincial capitals. In 2019, Fuzhou's financial industry value was over 100 billion yuan. Although when compared with the financial capitals of Guangzhou and Hangzhou, the overall scale of Fuzhou's financial industry remains relatively modest with an obvious economic gap, when compared with Nanjing and Jinan, Fuzhou exhibits certain advantages and development potential[20]. In terms of the proportion of services in the same period, Fuzhou's financial industry accounts for $19.97 \%$ of the total value of services, nearly onefifth of the total value. This demonstrates the prominent position and development achievements of Fuzhou's financial industry in the context of the entire service industry. Regarding the proportion of GDP in the same period, Hangzhou's financial industry leads, which can be attributed to the booming internet finance industry in Hangzhou[21]. However, Fuzhou's financial sector accounted for one-tenth of GDP in the same period, the secondhighest among the five cities. This also demonstrates that Fuzhou's financial industry plays a critical role in the regional economy and requires further support and high-quality development.

(1) The ecosystem of modern services is incomplete

Any service fault in the ecosystem of modern service industry will affect the service industry. The quality of the whole modern service industry will be affected by the basic supporting facilities of the service industry, the supplies needed by the service industry, the service consumables and so on. The modern service industry in Fuzhou is in the stage of development, lack of perfect ecological system, the traditional modern service industry operation mode cannot attract customers for a long time. For example, the catering industry in Fuzhou is mainly concentrated in one area, but the dense catering industry has not formed a one-stop catering service.

(2) The lack of data sensitivity in modern service industries

The modern service industry should keep up with the era of big data and get the optimal service 
management plan through big data analysis. No matter the transportation network service ecosystem or the choice of location advantages, it is necessary to combine big data analysis, collate and analyze the big data of modern service industry, and deduce a reasonable development path of service industry. In the development process of modern service industry in Fuzhou, there is lag of data response, and there is no analysis on consumers with the timeliness of big data, resulting in consumers not getting the best experience.

(3) The educational level of employees is low At present, the modern service employees in Fuzhou are faced with the situation that the higher education personnel are unwilling to engage in the basic modern service, while the lower education personnel are difficult to engage in the high-level modern service work. According to the survey results, due to the lack of vocational education in modern service industry, the cultural quality of employees in modern service industry is low, and problems such as learning difficulties occur in the process of introducing new equipment. In Fuzhou and even Fujian province, there are few vocational colleges and universities offering relevant majors for the development of modern service industry, resulting in an imbalance between employment and talent supply.

(4) Traffic congestion, traffic is not convenient

Modern service industries are based on vast and convenient transportation networks. On the one hand, the current traffic in Fuzhou mainly relies on simple transportation methods such as bus network, taxi booking and so on. Although Fuzhou has its own subway, only metro Line 1 is open at present, which cannot meet the needs of tourists. On the other hand, the nine modern service commercial districts are relatively concentrated, mainly located in the important traffic sections around the second ring Road, leading to the shortage of parking lots in each business district, coupled with the traditional way of parking intensified the traffic jam.

\section{Fuzhou's Development Proposal: Finance, Logistics, and Retail}

Fuzhou's service industry is structurally complex, wide in scope, and large in scale. This paper proposes several suggestions for promoting the high-quality development and modernization of Fuzhou's service industry in terms of prestigious, well-known industries, namely the financial, logistics, and retail industries.

\subsection{Smart Finance and Development of the Financial Industry}

The Fifth Plenary Session of the 19th CPC Central Committee proposed promotion of producer services for specialization and extension of the value chain. As the core of modern economics, the financial industry is the fusion agent and propellant of the market economy, a critical element of support for promoting the high-quality development of regional economies. We must substantially develop modern financial institutions and expedite the construction of a modern economic system. To realize the high-quality development of the modern service industry, Fuzhou must promote the development of the financial service industry. First, city officials should fully leverage political advantages and benefits of economic hub. Additionally, we should leverage the regional advantages of provincial capitals, thoroughly harness the siphon effect of various beneficial policies in the five zones, accelerate the construction of a modern financial center in Haixi, and adopt preferential policies to actively channel prosperity into Fuzhou and promote the agglomeration of financial industries and the integrity of industrial chains. Furthermore, we should encourage orderly competition to stimulate the internal driving force of the financial industry and increase the scale and power of Fuzhou's financial industry. Second, we should increase investment in financial resources and tailor the environment to the high-quality development of the financial sector. Additionally, we should improve policies related to rewards and support and strengthen existing policies related to the introduction and financing of prestigious financial talent to create a financial ecological region for facilitating the development of financial talent and financial technology innovation. Third, we should fully use the internet and big data as well as artificial intelligence and other new-generation information technologies to build a financial cloud platform and actively develop financial institutions that are inclusive, green, and technological advanced, among other features. Fuzhou can serve as a pilot project for financial reform by promoting smart finance to better facilitate the cultivation and growth of leading industries such as modern equipment manufacturing, integrated circuit software, and other innovative applications of information technology[22]. Furthermore, Fuzhou can promote the common growth of new financial industries and other new industries. Fourth, we should comprehensively promote Fujian's strategy for high-quality development and catch up with other financial centers by leveraging the regional 
advantages of being a provincial capital. Fujian will play an active role in promoting the construction of a distinctive cross-strait financial cooperation center, including a private economic and financial service center and a Hess industrial and financial center[23].

\subsection{Industrial Linkage and Development of the Logistics Industry}

The Fifth Plenary Session of the 19th CPC Central Committee proposed the acceleration and the development of modern logistics and legal services, among other services. With the extensive application of new information technology, the development of China's logistics industry has also entered a new stage of development[24]. Fuzhou has been selected as a national logistics hub, so determining how to apply new ideas to engender the high-quality development of Fuzhou's modern logistics industry is necessary. First, we should accelerate the development of high-quality modern logistics infrastructure and enhance the guidance and coordination of transportation hubs and logistics parks in terms of planning and layout. The modern logistics industry cluster can be optimized through further development of the Port of Fuzhou, the Fuzhou railway station, and Fuzhou Changle International Airport. Additionally, we should promote the in-depth integrated development of the port logistics and aviation logistics industries and build bonded port logistics centers. We can strengthen land security for the development of modern logistics, support the use of urban renewal resources to build characteristic industrial parks for the integrated development of modern logistics and other industries, and comprehensively promote the development of a national logistics hub and a model city for express delivery throughout China. Second, we should further improve public service platforms for the modern logistics industry by fully utilizing the internet, the Internet of Things, artificial intelligence, big data, and other technologies. We can promote and perfect the Single Window System for international trade and optimize logistics information nodes such as airports, ports, railways, and highways. We should expedite the construction of smart ports and realize paperless and intelligent customs clearance at ports and airports to construct a modern supply chain public service platform that is integrated with the transportation and manufacturing industries to provide basic functions with obvious public benefits. We should also explore and support large-scale transportation enterprises to provide public logistics services and expand the efficiency and coverage of logistics services. Third, we should promote the development of modern logistics supply chain enterprises into chain clusters, actively introduce large, leading domestic and foreign modern logistics and supply chain enterprises to Fujian and Fuzhou, and enact policies for financial support and encouragement. We should also encourage local logistics enterprises to strengthen and expand, and we should provide 24-h high-quality support to exceptional and highpotential logistics enterprises by providing financing, creating and issuing corporate bonds, encouraging talent to settle in Fuzhou, providing rent subsidies, and implementing other policies and measures[25]. Provincial industrial logistical parks such as the Port of Fuzhou, Fuzhou Changle International Airport, and Xiangfu Shipping Logistics Park of Jiangyin Port should be given full play to the leading role of of national railway logistics and other leading enterprises to direct cooperation among various logistics enterprises in shipping, aviation, and supply chain management and form an industrial alliance for integrating innovation and development.

\subsection{Digital Technology and the Development of the Retail Industry}

The Fifth Plenary Session of the 19th CPC Central Committee proposed accelerating the digitization of the service industry. With the current in-depth implementation of new information technology, the development of the digital economy, and the comprehensive application of digital technology in the service industry under epidemic and pandemic situations, lifestyles and channels, concepts, and patterns of consumption are undergoing profound transformation[26]. Fuzhou's retail industry should strive to modernize its business environment and steadily expand in scale. First, we should fully utilize the internet, big data, artificial intelligence, and other intelligent technologies to accelerate the digital enhancement of traditional business models and professional markets. Furthermore, we should create several modern business platforms and professional markets with exceptional, spacious layouts and extensive digitization. Second, we should adapt to the deepening digital economy, actively develop new business models and new types of business, and increase the digitization of the business economy. We should further promote supply chain enterprises as well as the online and offline integration of collaborative industry platforms, trading service platforms, and public service platforms to create a seamless connection between circulation and production services and communication[27]. Moreover, we should 
encourage Fuzhou to achieve the development goal of being the "new retail capital." Third, we should continue to promote the nightlife economy and create a unique Mindu culture in conjunction with the characteristics of the nightlife economy. Concurrently, we should leverage urban renewal opportunities to replan and rebuild experiential smart business circles to promote smart connectivity and the integrated sharing of advantages among various entities in the business circle under the circumstances of new models, new forms of business, and new services, further guiding the transition to intelligent, personalized services and services with distinctive features. Fourth, we should take full advantage of the characteristics of Mindu culture, including "two mountains, two towers, and two blocks" . Additionally, we should reveal and protect local time-honored brands in Fuzhou, and we should actively promote the cultivation and innovative development of trade brands. We can promote the integrated development of longestablished brands both online and offline, and we can build several time-honored brand crafting studios and museums to facilitate conservation and protection of local culture. We should actively cultivate several emerging local brands such as Pupu online market, substantially revitalize the development of Fujian cuisine, and establish new standards for the culture and identity of Fujian.

\section{Conclusion and Discussion}

\subsection{Conclusion}

In conclusion, the development and modernization of Fuzhou's service industry should be guided by Xi Jinping Thought on Socialism with Chinese Characteristics for a new era and should incorporate the spirit of the Fifth Plenary Session of the 19th CPC Central Committee. New development strategies should involve harnessing the region's benefits to consolidate its foundation and anticipate future opportunities. We should fully implement a new development philosophy, continue to enhance innovation, fully use our potential, and increase the resilience of future development. We should foster new types of business, activate new growth drivers, create new development models, expand our reach, and create a new development pattern to promote the high-quality development of Fuzhou's modern service industry[28].

6.2 Discussion

First of all, the specific classification standard of modern service industry is not clearly stipulated in China, so the classification method of modern service industry in this paper is defined by referring to the research experience of a large number of scholars and the suggestions given by relevant government departments, which may be biased to some extent in the statistical caliber[29]. Further studies will be conducted on the statistical caliber of modern service industry, but it is hoped that the state can specify the statistical caliber of modern service industry. Secondly, due to the numerous influencing factors of the development of modern service industry, the influencing factors may not be considered comprehensively in this paper[30]. In the next step, a large number of literatures will be consulted to expand the Angle of influencing factors. Finally, due to a large number of statistical indicators, a large amount of index data, and data is not easy to obtain, the research in this paper can only stay on the analysis of differences between regions in China, and then a more systematic, specific and deeper study will be conducted on a specific region, which will solve specific problems in a certain region.

\section{Acknowledgement:}

This research was financially supported by Fuzhou Social Science Planning Research Project under grant 2017FZA01.

\section{References:}

[1] Xia J.C. China's Service Industry towards 14th and 5th year: Key Breakthrough of trend Judgment and policy thinking. Journal of Beijing Technology and Business University, 2020(4) : 1-10+31

[2] Wu C.X. On other factors influencing the growth rate of added value in service industry. Beijing statistics, 2001(01) :21-22

[3] Philip Kotler. Market management: Analyze, plan, execution and control. Shanghai People's Publishing House, 1999.10

[4] Chen X.Y., Liu Sheng, Gu N.H. The institutional environment of regional service efficiency and the transformation and upgrading of foreign capital utilization: based on the perspective of supply-side structural reform of service industry. Finance and Trade Research, 2018(08) : 1-15.

[5] Feng T.W. The development of producer services affects the efficiency of manufacturing industry with transaction cost and manufacturing cost as intermediary variables. 
Quantitative \& technical economics, 2009(03) :56-65.

[6] Mukesh Eswaran, Ashok Kotwal. The role of the service sector in the process of industrialization[J]. Journal of Development Economics. 2002 (2)

[7] Wang S.L., Teng Z.W., Liu Jun. The difference analysis of productivity changes in China's service industry: based on regional and industry perspectives. Economic Research, 2015(08):7384

[8] Fasika Bete Georgise, Aman Hebana Heramo, Habte Bekele, Improving Automotive Service Through E-logistics: a Case of Moenco Hawassa, Ethiopia. International Journal of Economics and Management Systems, Vol. 5, 2020, pp. 21-40.

[9] Ahmad Moh'd Mansour, Internal Marketing and Service Quality in Jordanian Hotels, WSEAS Transactions on Environment and Development, Volume 16, 2020, pp. 831-843.

[10] Hollis Landrum, Victor R Prybutok, A service quality and success model for the information service industry, European Journal of Operational Research,

Volume 156, Issue 3, 2004, pp 628-642,

[11] Shuimei Wang. The Strategy Research of Modern Service Industry Development. Asian Social Science. Vol. 8, No. 2, 2012, pp185-188

[12] Herbert G. Grubel, Michael A. Walker. Modern Service Sector Growth: Causes and Effects. Services in World Economic Growth 1st Edition. 1989, pp34

[13] Alan S. Miller. Conventional Religious Behavior in Modern Japan: A Service Industry Perspective. Journal for the Scientific Study of Religion

Vol. 31, No. 2, 1992), pp. 207-214.

[14] Xiaozhong, Jing Hu. Study on Modern Service Industry Based on the Industrial Cluster. Proceedings of the 2nd International Conference on Green Communications and Networks 2012 (GCN 2012): Volume 3 pp 189-194.

[15] Rui Tang \& Pishi Xiu (2021) The modern service industry agglomeration and tourism efficiency in China: regional difference and influencing mechanism, Journal of the Asia
Pacific Economy, DOI: 10.1080/13547860.2021.1955529.

[16] Ying Li, Zhiling Luo. Enterprise Pattern: integrating the business process into a unified enterprise model of modern service company. Enterprise Information Systems. Vol.11, 2017, pp37-57

[17] Robert W. Zmud. Diffusion of Modern Software Practices: Influence of Centralization and Formalization. Management Science, Vol. 28 , No.12, https://doi.org/10.1287/mnsc.28.12.1421

[18] Zhaohui Wu, etc. Modern Service Industry and Crossover Services: Development and Trends in China. IEEE Transaction on Service Computing. Vol.9, pp664-671.

[19] Guoqin Song, Junjie Zhang. A Research on Modern Service Industry Innovation and Its Development Strategy. Proceedings of the Sixth International Conference on Management Science and Engineering Management. Springer,.

[20] Ji-Fang XING. An Analysis of the Development of Modern Service Industry in China's National Strategy. 2016 International Conference on Service Science, Technology and Engineering (SSTE 2016).pp 573-578.

[21] Yi Man. Research of methodology of building modern service industry BI system based on NGOSS. The Journal of China Universities of Posts and Telecommunications. Vol. 15, pp8487.

[22] Prachi Agarwal. Modern Services in India Policymaking and Governance. www.cepal.org.

[23] Yacui Zhang. Research on the Integration Development of Advanced Manufacturing Industry and Modern Service Industry in Shaanxi. 2019 6th Asia-Pacific Conference on Social Sciences, Humanities (APSSH 2019), pp590-593

[24] Piera Centobelli, Roberto Cerchione, Emilio Esposito, Environmental sustainability in the service industry of transportation and logistics service providers: Systematic literature review and research directions, Transportation Research Part D: Transport and Environment, Volume 53, 2017, Pages 454-470 
[25] Ping-Lung Huang, Bruce C.Y. Lee \& ChingChin Chen (2019) The influence of service quality on customer satisfaction and loyalty in B2B technology service industry, Total Quality Management \& Business Excellence, 30:13-14, 1449-1465

[26] Benjamin Yeo, Delvin Grant, Predicting service industry performance using decision tree analysis, International Journal of Information Management, Volume 38, Issue 1,2018,Pages 288-300

[27] Delvin Grant, Benjamin Yeo,

A global perspective on tech investment, financing, and ICT on manufacturing and service industry performance, International Journal of Information Management, Volume 43, 2018, Pages 130-145

[28] Delvin Grant, Benjamin Yeo, A global perspective on tech investment, financing, and ICT on manufacturing and service industry performance, International Journal of Information Management, Volume 43, 2018, Pages 130-145

[29] Myunghee Mindy Jeon, Seonjeong Lee, Miyoung Jeong, Perceived corporate social responsibility and customers' behaviors in the ridesharing service industry, International Journal of Hospitality Management, Volume 84, 2020, 102341

[30] National Bureau of Statistics. China Statistical Yearbook[M]. Beijing: China Statistics Press, 2015 (in Chinese).
Creative Commons Attribution License 4.0 (Attribution 4.0 International, CC BY 4.0) This article is published under the terms of the Creative Commons Attribution License 4.0 https://creativecommons.org/licenses/by/4.0/deed.en US 